\title{
Elevated atmospheric CO2 and humidity delay leaf fall in Betula pendula, but not in Alnus glutinosa or Populus tremula $x$ tremuloides
}

Article

Accepted Version

Godbold, D. L., Tullus, A., Kupper, P., Sober, J., Ostonen, I., Smith, A., Godbold, J. A. and Lukac, M. (2014) Elevated atmospheric $\mathrm{CO} 2$ and humidity delay leaf fall in Betula pendula, but not in Alnus glutinosa or Populus tremula $\times$ tremuloides. Annals of Forest Science, 71 (8). pp. 831-842. ISSN 1286-4560 doi: https://doi.org/10.1007/s13595-0140382-4 Available at https://centaur.reading.ac.uk/36635/

It is advisable to refer to the publisher's version if you intend to cite from the work. See Guidance on citing.

To link to this article DOI: http://dx.doi.org/10.1007/s13595-014-0382-4

Publisher: Springer

All outputs in CentAUR are protected by Intellectual Property Rights law, including copyright law. Copyright and IPR is retained by the creators or other copyright holders. Terms and conditions for use of this material are defined in the End User Agreement. 


\section{www.reading.ac.uk/centaur}

\section{CentAUR}

Central Archive at the University of Reading

Reading's research outputs online 
1 Elevated atmospheric $\mathrm{CO}_{2}$ and humidity delays leaf fall in Betula pendula,

2 but not in Alnus glutinosa or Populus tremula $\times$ tremuloides.

4 Executive Summary

5 The effects of both elevated atmospheric $\mathrm{CO}_{2}$ and increased air humidity on

6 autumn leaf fall were assessed using free air systems. Both factors delayed leaf

7 litter fall in Betula pendula, but not in Populus tremula $\times$ tremuloides or Alnus

8 glutinosa.

9

10 Abstract

11 Context: Anthropogenic activity has increased the level of atmospheric $\mathrm{CO}_{2}$,

12 which is driving an increase of global temperatures and associated changes in

13 precipitation patterns. At Northern latitudes, one of the likely consequences of

14 global warming is increased precipitation and air humidity.

15 Aims: In this work, the effects of both elevated atmospheric $\mathrm{CO}_{2}$ and increased air

16 humidity on trees commonly growing in northern European forests were assessed.

17 Methods: The work was carried out under field conditions by using Free Air

18 Carbon dioxide Enrichment (FACE) and Free Air Humidity Manipulation

19 (FAHM) systems. Leaf litter fall was measured over 4 years (FACE) or 5 years

20 (FAHM) to determine the effects of FACE and FAHM on leaf phenology.

21 Results: Increasing air humidity delayed leaf litter fall in Betula pendula, but not

22 in Populus tremula $\times$ tremuloides. Similarly, under elevated atmospheric $\mathrm{CO}_{2}$,

23 leaf litter fall was delayed in Betula pendula, but not in Alnus glutinosa. Increased 
$24 \mathrm{CO}_{2}$ appeared to interact with periods of low precipitation in summer and high

25 ozone levels during these periods to effect leaf fall.

26 Conclusions: This work shows that increased $\mathrm{CO}_{2}$ and humidity delay leaf fall,

27 but this effect is species specific.

29 Keywords: climate change, Free Air $\mathrm{CO}_{2}$ Enrichment (FACE), Free Air Humidity

30 Manipulation, leaf fall, ozone

\section{Introduction}

Anthropogenic activities since the industrial revolution have increased 34 atmospheric $\mathrm{CO}_{2}$ concentrations (IPCC 2013), leading not only to climate 35 warming, but also to direct effect of elevated $\mathrm{CO}_{2}$ on forest net primary 36 productivity (NPP, Norby et al. 2005). In addition, climate change is predicted to 37 increase precipitation at Northern latitudes (IPCC 2013), likely leading to an 38 increase in air humidity. For example, in the Baltic region climate change 39 scenarios for the year 2100 predict an increase in air temperature (by $2.3-4.5^{\circ} \mathrm{C}$ ), 40 precipitation (by 5-30\%), cloudiness (by $2 \%$ ), but also higher wind speeds and 41 vapour pressure (Kont et al. 2003). Studies investigating the impact of global 42 environmental change on terrestrial ecosystems have identified a consistent 43 pattern of phenological change in the Northern hemisphere (IPCC 2013). Analysis 44 of normalised difference vegetation index (NDVI) remote sensing data gathered 45 during 1985-1999 has revealed an 18 day extension of the growing season in 46 Eurasia (Zhou et al. 2001). Multiple drivers have been shown to differentially 
47 influence plant phenophases, earlier bud break has been correlated with

48 atmospheric warming and delayed senescence (Menzel et al. 2006) and

49 interactions between temperature and elevated atmospheric $\mathrm{CO}_{2}$ concentrations

50 have been described (Taylor et al. 2008). The process of senescence is governed

51 by developmental age, but also influenced by various integrated endogenous and

52 environmental signals (Lim et al. 2007). Environmental factors influencing leaf

53 senescence can be grouped into: (i) abiotic factors that include drought, nutrient

54 limitation, extreme temperatures, ozone induced oxidative stress, and (ii) biotic

55 factors including, pathogen infection or shading by other plants ( $\mathrm{Li}$ et al. 2000).

56 Endogenous factors influencing senescence include carbon source-sink

57 relationships, phytohormones, particularly jasmonic (JA) and abscisic acid

58 (ABA), ethylene and salicylic acid (SA). The aforementioned phytohormones

59 initiate senescence through cellular signalling pathways in response to various

60 abiotic and biotic stresses that promote the expression of senescence inducing

61 genes (Morris et al. 2000).

62 Elevated atmospheric $\mathrm{CO}_{2}$ has shown been to increase long term forest net

63 primary productivity (Zak et al. 2011), if nutrients are not limiting (Leutzinger

64 and Hätenschwiler 2013). However studies of the effects of elevated atmospheric

$65 \mathrm{CO}_{2}$ on tree autumnal phenophase have produced conflicting results. For example,

66 elevated $\mathrm{CO}_{2}$ advanced senescence in two varieties of Pinus ponderosa (Houpis et

67 al. 1988) and also in Populus trichocarpa (Sigurdsson 2001), yet delayed

68 senescence of Quercus myrtifolia (Li et al. 2000) and Populus species grown in

69 freely rooted field conditions during the AspenFACE and POPFACE studies 
70 (Taylor et al. 2008). At the DukeFACE experiment, however, no effect on leaf

71 phenology was observed in Liquidambar styraciflua (Herrick and Thomas 2003).

72 Air water vapour content determines the vapour pressure difference between

73 ambient air and leaf interior $\left(\mathrm{VPD}_{\mathrm{L}}\right)$, a gradient which drives the transpiration

74 process of plant foliage. At higher relative humidity, both $\mathrm{VPD}_{\mathrm{L}}$ and

75 transpirational flux decrease, which has been demonstrated in the Free Air

76 Humidity Manipulation (FAHM) experiment in both Betula pendula Roth and

77 Populus tremula L. $\times$ P. tremuloides Michx. in rainy summers when soil water

78 content is not limiting in ambient conditions (Kupper et al. 2011; Tullus et al.

79 2012a). It has been shown that elevated humidity diminishes nutrient supply to the

80 leaves and photosynthetic capacity, altering foliar and fine-root properties and tree

81 growth rate (Tullus et al. 2012a; Hansen et al. 2013; Parts et al. 2013; Sellin et al.

82 2013). However, the effect of air humidity changes on leaf fall in trees has not

83 been studied to date.

84 Natural autumnal senescence is regulated by the interaction of a number of factors

85 including day length and temperature, nitrogen and water supply, as well as sink

86 strength within the plant (Wingler et al. 2006). Thus, changes in the timing of leaf

87 senescence are governed by, amongst other factors, assimilation during the

88 vegetation period and sugar accumulation in leaves (Swartzberg et al. 2010).

89 Several studies utilising molecular genetic approaches have indicated that high

90 concentrations of leaf sugars reduce photosynthetic activity, which in turn induces

91 leaf senescence (Swartzberg et al. 2010). In Acer saccarinum, girdling resulted in

92 increased sugar accumulation in leaves, and subsequent formation of anthocyanins 
93 (Murakami et al. 2008), whilst increased anthocyanin content in another study

94 utilising the same species was associated with a delay in leaf senescence

95 (Schaberg et al. 2008). Furthermore, transcriptome analysis of Populus trees

96 grown under elevated $\mathrm{CO}_{2}$ in field conditions revealed up-regulation of genes

97 determining anthocyanin production during delayed senescence (Tallis et al.

98 2010). These authors suggest that anthocyanins may play a protective role in leaf

99 metabolism and increase leaf longevity.

100 In the work presented here we investigated the effect of two factors of global 101 climate change, atmospheric $\mathrm{CO}_{2}$ and humidity, on autumn leaf fall. We 102 speculated the effects of both of these factors were tree species specific. Thus, we 103 hypothesised that (i) elevated $\mathrm{CO}_{2}$ delays and (ii) elevated atmospheric humidity 104 anticipates leaf senescence in broadleaved species.

106 Material and Methods

107 The investigation was carried out at two sites, a Free Air Carbon dioxide

108 Enrichment experiment (BangorFACE) and a Free Air Humidity Manipulation

109 (FAHM) experiment.

\section{The FACE facility}

111 The BangorFACE experimental site was established in March 2004 on two former 112 agricultural fields with a total area of 2.36 ha at the Bangor University research 113 farm $\left(53^{\circ} 14^{\prime} \mathrm{N}, 4^{\circ} 01^{\prime} \mathrm{W}\right)$ in North Wales, UK. Both fields were originally 114 pastures, one field was used for small scale forestry experiments for the last 20 115 years, the other field was ploughed and planted with oil seed rape in 2003. 
116 Climate at the site is classified as Hyperoceanic, with a mean annual temperature

117 in 2005 through 2008 of $11.5^{\circ} \mathrm{C}$ and an annual rainfall of $1034 \mathrm{~mm}$ (Figure 1a).

118 Soil is a fine loamy brown earth over gravel (Rheidol series) and classified as

119 Fluventic Dystrochrept (Smith et al. 2013a). Soil texture is 63\% sand, 28\% silt and $9 \%$ clay. The topography consists of a shallow slope of approximately $1-2^{\circ}$ on a deltaic fan. The site aspect is northwesterly, with an altitude of 13 to $18 \mathrm{~m}$ a.s.l. The depth of the water table ranges between 1 and $6 \mathrm{~m}$.

At the BangorFACE site eight octagonal plots, four ambient and four $\mathrm{CO}_{2}$ enriched were established, creating a $2 \times 4$ factorial block design across the two fields. Three tree species (Alnus glutinosa [L.] Gaertner, Betula pendula Roth. and Fagus sylvatica L.) were selected due to their contrasting shade tolerance, successional chronology and to represent a range of taxonomic, physiological and ecological types. Each plot was divided into seven planting compartments and planted in a pattern creating areas of one, two and three species mixtures. The present study makes use of observations originating from three single species subplots of B. pendula and A. glutinosa. The site was planted with $60 \mathrm{~cm}$ saplings of each species. Within each treatment, the planting pattern was rotated by $90^{\circ}$ between the four plots to avoid potential artefacts introduced by microclimate, soil and uneven growth rates of the different species. Each plot was surrounded by a $10 \mathrm{~m}$ border of $B$. pendula, A. glutinosa and $F$. sylvatica planted at the same density. The remaining field was planted at a $1 \mathrm{~m}$ hexagonal spacing with a mixture of birch (B. pendula), alder (A. glutinosa), beech $(F$. sylvatica $\mathrm{L}$.$) , ash$ 
139 sativa Mill.) and oak (Quercus robur L.). To protect the saplings, the entire 140 plantation was fenced.

141 Carbon dioxide enrichment was carried out using high velocity pure $\mathrm{CO}_{2}$

142 injection, with a target concentration in the FACE plots as ambient plus $200 \mathrm{ppm}$

143 (Smith et al. 2013a). The elevated $\mathrm{CO}_{2}$ concentrations, measured at 1 minute

144 intervals, were within $30 \%$ deviation from the pre-set target concentration of 580

$145 \mathrm{ppm} \mathrm{CO}_{2}$ for $75-79 \%$ of the time during the photosynthetically active part of 2005

$146-2008$ (Smith et al 2013a). Vertical profiles of $\mathrm{CO}_{2}$ concentration measure at 50

$147 \mathrm{~cm}$ intervals through the canopy showed a maximum difference of $7 \%$.

148 Air temperature and precipitation were monitored using an automatic weather 149 station (Campbell Scientific, Logan, UK) sampling at $3 \mathrm{~m}$ above the ground at 150 hourly intervals Ground level ozone concentration was measured at a DEFRA air 151 quality monitoring station at Aston Hill $\left(52^{\circ} 30^{\prime} \mathrm{N}, 3^{\circ} 02^{\prime} \mathrm{W}\right) \mathrm{ca} .50 \mathrm{~km}$ from

152 BangorFACE at hourly intervals, and was matched to measurements made at the 153 Centre for Ecology and Hydrology ozone research facility directly next to the 154 BangorFACE site $\left(53^{\circ} 14^{\prime} \mathrm{N}, 4^{\circ} 01^{\prime} \mathrm{W}\right)$.

\section{FAHM facility}

157 The Free Air Humidity Manipulation (FAHM) experimental facility is located at 158 Järvselja Experimental Forest District in South-East Estonia $\left(58^{\circ} 14^{\prime} \mathrm{N}, 2^{\circ} 18^{\prime} \mathrm{E}\right)$.

159 The study area lies in the northern part of the temperate climate zone in the 160 transition zone between maritime and continental climate. The study period 161 comprised two growing seasons with drought conditions (2010 and 2011) and 
three with average precipitation conditions (2008, 2009 and 2012) (Figure 1b).

163 Soil is classified as Endogleyic Planosol (Hansen et al. 2013). The FAHM site is a

1642.7 ha fenced area, previously used for agriculture, where nine experimental circle

165 plots are situated. Three experimental plots act as control plots. In three plots the

166 relative air humidity $(\mathrm{RH})$ is elevated by approximately $7 \%$ over ambient level

167 using a misting technique (water is vaporized to a droplet size ca $10 \mu \mathrm{m}$ ) and

168 FACE-like technology to mix humidified air inside the plots (for more detailed

169 technical description see Kupper et al. 2011 and Tullus et al. 2012a).

170 Humidification is applied when ambient $\mathrm{RH}<75 \%$, air temperature $>10{ }^{\circ} \mathrm{C}$ and

171 wind speed $<4 \mathrm{~m} / \mathrm{s}$. Three experimental plots were "open-top" plots from 2009-

1722011 and are not included in the current study. Half of each plot was planted with

173 silver birch (Betula pendula Roth) and another half with hybrid aspen (Populus

174 tremula L. $\times$ P. tremuloides Michx.) in 2006. The experimental plots are

175 surrounded by a buffer zone, composed of hybrid aspen. Humidity manipulation

176 experiment started in 2008 and has been running during all growing seasons

177 (May-Oct) since then. The first experimental period with Betula pendula ended in

178 2011, after that a new birch generation was established with planted seedlings.

179 Hybrid aspens were cut in 2012 and a new generation emerged as regrowth roots

180 and stumps.

181 Air temperature and precipitation were monitored using an automatic weather

182 station (Campbell Scientific, Logan, UK) collecting in 10 minute intervals at $6 \mathrm{~m}$

183 above the ground. Temperature data were collected in 10 minute intervals. Winter 
precipitation (snow) data was obtained from the Estonian Environment Agency's weather station, situated ca. $70 \mathrm{~km}$ from the FAHM site.

\section{Litter collection}

188 BangorFACE

189 Following observation of leaf fall, fallen leaf litter was collected at weekly 190 intervals using litter baskets with an area of $0.11 \mathrm{~m}^{2}$ until all leaves had abscised 191 (September to December). A litter basket was located in each of the single species 192 subplots. Litter was returned to the laboratory on the day of collection, washed and sorted into individual species, and then dried at $80{ }^{\circ} \mathrm{C}$ for 24 hours. The dry 194 weight of each species was determined and recorded for each species subplot 195 within each ambient and elevated $\mathrm{CO}_{2}$ plot. Fagus sylvatica was not used as senesced leaves remained attached until bud burst the following spring. Leaf

197 retention was calculated by subtracting fallen litter at each sampling collection 198 from the total fallen litter after all the leaves had abscised.

199

200

\section{FAHM}

201 Litter was collected from three control (C) and three humidified $(\mathrm{H})$ plots. Under

202 both Betula pendula and hybrid aspen, two litter baskets $\left(0.21 \mathrm{~m}^{2}\right)$ per species 203 were installed. Litter collection started in the end of July/beginning of August and 204 continued in ca 2-week interval until all leaves had abscised (usually by mid-

205 November). Birch litter was collected during four experimental years (2008206 2011), after that the first generation of birch trees was harvested. Populus tremula 
$\times$ tremuloides litter was collected during five years (2008-2012), after which the

208 first generation of aspen was removed. Litter samples were dried at $70{ }^{\circ} \mathrm{C}$ to

209 constant weight and dry mass of the samples was determined. Leaf retention was

210 calculated as described above.

212 Data analysis

213 Generalized additive mixed models (GAMMs; Zuur et al., 2007; Wood, 2008)

214 were used to describe the percentage change in remaining leaf mass at each

215 collection date between ambient and treatment plots. Visual assessments of

216 variograms and residuals vs. fitted values found weak evidence of temporal

217 autocorrelation. However, as the time series consisted of $<20$ data points, it was

218 more appropriate to model the variance structure, rather than the autocorrelation

219 structure (Zuur et al. 2009). For Alnus glutinosa and Populus tremula data

220 exploration indicated violation of homogeneity of variances as a result of

221 differences between FACE rings and precipitation respectively. As a result, we

222 used a random effects model to model variability caused by the factor "Ring" (for

223 A. glutinosa) and the variable "precipitation" (for P. tremula). The additive

224 (GAM; Betula pendula) and additive mixed models (GAMM; A.glutinosa, P.

225 tremula) were modelled with a binomial distribution and a logistic link function

226 (Zuur et al. 2009). For both the FAHM and FACE analyses, the initial models of

227 the GAMs and GAMMs included a smoother over "Collection Day" (s(Days)),

228 the factors "Treatment" (ambient or elevated), "Year", as well as "Precipitation"

229 and "Ozone" for the FACE analyses and "Precipitation" and "Temperature" for 
the FAHM analyses. To estimate the optimal amount of smoothing for each smoother, we used cross-validation (Zuur et al., 2009) and alternative models were compared using the Akaike information criterion (AIC). Once the optimal model was identified, the residuals were re-examined to ensure that model assumptions were met. Analyses were conducted in R (R Development Core Team 2014) and the "mgcv" library for additive (mixed) models (Wood, 2014).

\section{Results}

\section{Environmental factors}

239 At BangorFACE during the four-year experiment period, in the summers of both 2402006 and 2008 there were two consecutive months with extremely low

241 precipitation (Figure 1a). These months were June and July in 2006, and May and 242 June in 2008. In 2006 the highest summer temperature of the period under 243 observation was reached. The highest temperature of $34.3^{\circ} \mathrm{C}$ (Table 1) was 244 recorded in July 2006 during a week long period of very high temperatures. 245 Accumulative ozone over the threshold of $40 \mathrm{ppb}\left(\mathrm{AOT}_{40}\right)$ was highest during 2462006 , with daily peaks in excess of $210 \mathrm{ppb}$. In 2008, over the year neither 247 cumulative precipitation was very low nor was cumulative $\mathrm{AOT}_{40}$ very high. 248 However, during the low rainfall months of May and June, $50 \%$ of the total 249 annual $\mathrm{AOT}_{40}$ excedance occurred and levels of over $170 \mathrm{ppb}$ were reached. 250 Based on the growing degree days (GDD) and maximum temperature, 2007 was 251 the coolest of the 4 years (Table 1). 
252 At the FAHM site, the five-year experiment period also included two consecutive 253 years with conditions of drought in the middle of the growing season; 2010 and

254 2011. The year 2010 was the warmest of the 5 years of the investigation, with ca. 255 double the number of growing degree days compared to 2008 and 2012 (Table 1).

256 The year 2011 was the driest year for plant growth as spring precipitation was low 257 (Figure 1b).

258

259 Leaffall

260 At both the FAHM and the BangorFACE sites, based on weekly observations the 261 timing of budburst was not affected by either elevated humidity or $\mathrm{CO}_{2}$, respectively. The autumn leaf fall at the FAHM site was modelled using a GAMM for Populus tremula $\times$ tremuloides and a GAM for Betula pendula. The curves of the measured data (Figure 2) and the modelled data (Figure 3) showed a high degree of agreement. In Populus tremula $\times$ tremuloides, the $\mathrm{r}^{2}$ for the GAMM fit was $97 \%$, and in Betula pendula the $\mathrm{r}^{2}$ for the GAM fit was $95 \%$. At the FAHM site, different patterns of leaf fall were observed between Betula pendula and Populus tremula $\times$ tremuloides (Figure 2). In Betula pendula fall began earlier and continued over an 8-9 week period, where as in Populus tremula $\times$

270 tremuloides ca $80 \%$ of the leaves were lost within a two week period. In all study 271 years the leaf fall of Betula pendula was significantly delayed (Figure 3, Table 2) and slower in the increased humidity plots $(\mathrm{p}<0.0001)$, while such a consistent trend was not detected in Populus tremula $\times$ tremuloides $(\mathrm{p}<0.0001)$. In 2010, in

274 Populus tremula $\times$ tremuloides leaf fall was significantly earlier in the increased 
275 humidity plots ( $p<0.0001$, Figure 3 ). Generally, in hybrid aspen, leaf fall started

276 later and lasted for a shorter period. In control plots, leaf fall of Betula pendula

277 began in the first half of August, whereas in the increased humidity plots leaves

278 started to fall almost 4 weeks later (Figure 2). Litter fall dynamics in both Populus

279 tremula $\times$ tremuloides and Betula pendula appeared to be dependent on annual

280 weather conditions. Litter fall started earlier and more vigorously in the years

2812010 and 2011 with dry summers (Figure 1b). But Betula pendula litter dynamics

282 were also affected by increased humidity even in wet years (Figures 1a, 2and 3).

283 However, in the modelled data, inclusion of the treatment factors temperature and

284 precipitation did not improve the GAM, and both variables were removed during

285 the backward selection procedure. The prolonged leaf retention in Betula pendula

286 meant that the time of 50\% leaf fall was reached ca. 21 days later in the increased

287 humidity plots (Table 2). However, the duration to $100 \%$ leaf fall did not differ

288 between the ambient and humidity treatment.

289 At BangorFACE, a similar pattern of leaf loss was observed in Betula pendula 290 and Alnus glutinosa. Again the curves of the measured data (Figure 4) and the 291 modelled data (Figure 5) showed a high degree of agreement, with the exception 292 of Betula pendula in 2007. In Alnus glutinosa, the $\mathrm{r}^{2}$ for the GAMM fit was 95\%, 293 and in Betula pendula the $\mathrm{r}^{2}$ for the GAM fit was $89 \%$. Inclusion of the factors 294 temperature, precipitation and ozone did not improve the GAM or GAMM, and 295 again these variables were removed during the backward selection procedure. In 296 Alnus glutinosa, in 2007 leaf loss was significantly earlier in both ambient and 297 elevated atmospheric $\mathrm{CO}_{2}$ compared to the other years (Figures 4 and 5, Online 
298 Resource 1). In Alnus glutinosa, leaf fall was not significantly affected by 299 elevated atmospheric $\mathrm{CO}_{2}$ (Figure 5, Online Resource 1). In contrast in Betula 300 pendula leaf fall was delayed by elevated atmospheric $\mathrm{CO}_{2}$ in the years 2006 and 3012008 based on the measured data (Figure 4), and in all years based on the 302 modelled data (Figure 5, Online Resource 1). In 2006, litter collection was 303 initiated on the $20^{\text {th }}$ September (day 263). Under ambient $\mathrm{CO}_{2}, 3$ weeks later on 304 the $11^{\text {th }}$ October (day 283), $61 \%$ of the Betula pendula leaf canopy was still 305 retained in the crowns. In comparison under elevated $\mathrm{CO}_{2}, 80 \%$ of the leaf canopy 306 was still present in the crowns of the trees on the same date. Under elevated $\mathrm{CO}_{2}$, 307 Betula pendula still had $61 \%$ of the total canopy 14 days later on the $25^{\text {th }}$ October 308 (day 298), thus extending the life span of the canopy (Table 1). In 2008, litter 309 collection started on the $26^{\text {th }}$ September (day 269), and by the $24^{\text {th }}$ October (day 310 297) in the ambient plots $96 \%$ of the leaf canopy had fallen. Under elevated $\mathrm{CO}_{2}$, 311 on the $24^{\text {th }}$ October $89 \%$ of the canopy had fallen, and to reach a level of $96 \%$ a 312 further 12 days were required.

\section{Discussion}

315 Plant leaf senescence is a complex process predominantly influenced by 316 environmental factors such as temperature, light, nitrogen availability and soil 317 moisture. An example of this was seen in Alnus glutinosa, were early leaf fall in 3182007 occurred in the coolest of the four years. In addition, plant physiological 319 interactions which affect leaf senescence include phytohormones, leaf sugar 320 content and source-sink status of the plant (Winger et al. 2006; Taylor et al. 
2008). The data presented here show that elevated $\mathrm{CO}_{2}$ and increased humidity both result in two to three weeks longer leaf retention in Betula pendula. This

323 effect was not seen in either Alnus glutinosa under elevated $\mathrm{CO}_{2}$ or in hybrid 324 aspen (Populus tremula $\times$ tremuloides) under increased humidity. On the contrary, 325 in one year, 2010, in Populus tremula $\times$ tremuloides under increased humidity leaf 326 fall was earlier. However, the effect of elevated $\mathrm{CO}_{2}$ on leaf retention in Betula 327 pendula also appears modified by interactions with other environmental factors, 328 such as periods of drought, high temperature and high levels of ozone. Also in 329 Populus tremula $\times$ tremuloides the shorter retention occurred in the warmest year 330 (2010).

331 Plant growth in an elevated $\mathrm{CO}_{2}$ atmosphere is often associated with increased 332 accumulation of leaf starch and sugars, whilst leaf $\mathrm{N}$ is reduced (Ainsworth and 333 Long 2005). Studies of Arabidopsis have demonstrated that leaf senescence can 334 be induced by low $\mathrm{N}$ availability, and that $\mathrm{N}$ deficiency can result in leaf sugar 335 accumulation (Pourtau et al. 2004). In support of this, leaf $\mathrm{N}$ of Quercus 336 myrtifolia in summer was lower under elevated $\mathrm{CO}_{2}$ than under ambient $\mathrm{CO}_{2}$, but 337 higher in autumn ( $\mathrm{Li}$ et al. 2000). The higher autumn leaf $\mathrm{N}$ contents were related 338 to delayed leaf fall. At BangorFACE, N contents of Betula pendula and Alnus 339 glutinosa leaves were not changed under elevated $\mathrm{CO}_{2}$ (Smith et al. 2013a) during 340 the summer, and in Betula pendula in the autumn (Ferreira et al. 2010). No autumnal leaf $\mathrm{N}$ data are available for Alnus glutinosa. In contrast, $\mathrm{N}$ content in 342 both Betula pendula and hybrid aspen leaves were significantly lower in increased 343 humidity plots in rainy summers (Tullus et al. 2012a; Sellin et al. 2013). This 
344 indicates that in species under consideration, a change in leaf $\mathrm{N}$ status is not a

345 common factor related to longer leaf retention. A generally consistent response to

346 the process of leaf senescence is an increase in sugar content (Quirino et al. 2001).

347 Complex interactions during sugar metabolism could help to explain these

348 observations, which are supported by the results of a sugar maple (Acer

349 saccharum) girdling experiment where leaf sugar accumulation initiated the

350 formation of anthocyanin, a molecule associated with delayed senescence

351 (Murakami et al. 2008). Furthermore, using Populus spp., specific cDNA

352 microarrays up-regulated gene expression of leucoanthocyanidn dioxygenase

353 (LDOX) and dihydroflavonol reductase (DRF), two enzymes involved in the

354 biosythesis of anthocyanin were observed, in addition to increased autumnal leaf

355 sugar accumulation (Tallis et al. 2010). At BangorFACE, Betula pendula glucose

356 and total soluble sugars leaf content were increased in leaves collected during

3572006 under elevated $\mathrm{CO}_{2}$, whereas only the contents of glucose increased in Alnus

358 glutinosa (Ahmed 2006).

359 Cytokinins are known to delay leaf senescence (Yong et al. 2000), and usually an

360 excellent negative correlation between leaf cytokinin content and autumnal

361 phenophase exists during senescence (Buchanan-Wollaston 1997). However, the

362 physiology and biochemistry relating to the production of cytokinins and their

363 interactions with senescence processes are poorly understood. Many researchers

364 consider cytokinins to be predominantly root-sourced plant hormones, which are

365 translocated from the roots through the xylem (Dong et al. 2008). The supposition

366 that cytokinin synthesis occurs primarily in roots was supported by the discovery 
367 of IPT-genes that control cytokinin synthesis in plants (Chang et al. 2003). As

368 elevated $\mathrm{CO}_{2}$ has been shown to increase carbon allocation to roots and 369 mycorrhizal symbionts (Iverson et al. 2010), elevated $\mathrm{CO}_{2}$ may also raise 370 cytokinin production and subsequently increase leaf cytokinin concentrations. In 371 the BangorFACE experiment the leaf area index was not different between 372 ambient and elevated $\mathrm{CO}_{2}$ (Smith et al. 2013a), but the numbers of root tips in 373 Betula pendula were increased by 31 and $41 \%$ in 2006 and 2008 under elevated $374 \mathrm{CO}_{2}$, and in Alnus glutinosa a decrease or a $20 \%$ increase were found in 2006 and 3752008 respectively (Smith et al. 2013b). Similarly, under FAHM, in Betula 376 pendula the root tip frequency per DW was $20 \%$ and 7\% higher in 2009 and 377 2010, respectively (Parts et al. 2013), and the number of root tips $\mathrm{m}^{-2}$ was 378 increased by $42 \%$ compared to ambient in 2011 (Ostonen, unpublished), but no 379 data are available for hybrid aspen. A feedback mechanism involving a higher 380 number of root tips and thus greater cytokinin production has the potential to 381 explain the longer leaf retention under FACE and FAHM. An increase in fine root 382 growth is a common feature in trees under elevated $\mathrm{CO}_{2}$, and has been suggested 383 to be due to high $\mathrm{C}$ allocation to roots, but also as a mechanism to increase 384 nutrient uptake to meet the demand of increased aboveground growth (Smith et al. 385 2013a). Similarly, elevated humidity increased specific fine-root length (SRL) 386 increase in Betula pendula and was interpreted as a morphological adaptation 387 leading to an increase in the absorptive area to facilitate nutrient uptake (Parts et 388 al. 2013). 
389 At BangorFACE, the years of longer leaf retention, 2006 and 2008, were

390 characterised by periods of low precipitation for 2 successive months in the

391 summer and high tropospheric $\mathrm{O}_{3}$ concentration during this period. The

392 physiological mechanisms behind this effect can only be speculated upon. Both

$393 \mathrm{O}_{3}$ (Yendrek et al. 2013) and elevated $\mathrm{CO}_{2}$ (Eamus and Jarvis 1989) have been

394 shown to reduce stomatal conductance, and thus reduce instantaneous leaf water

395 loss. Further, as $\mathrm{O}_{3}$ has been reported to directly contribute to earlier leaf

396 senescence (Yendrek et al. 2013), lower stomatal conductance under elevated $\mathrm{CO}_{2}$

397 may reduce $\mathrm{O}_{3}$ exposure. Common to both FACE and FAHM is the potential to

398 lower transpiration loss either through lower stomatal conductance (in FACE) or

399 through lower water vapour pressure gradient (in FAHM). Higher water retention

400 by the ecosystem throughout the growing season may lead to lower cumulative

401 water stress in dry summers. Alternatively, the higher root biomass as discussed

402 above may be beneficial in drier periods and also contribute to lower cumulative

403 water stress. However, it should also be noted that both Alnus glutinosa and

404 Populus tremula $\times$ tremuloides displayed varying leaf fall pattern compared to

405 Betula pendula.

407 Conclusions

408 Two separate experiments, one increasing atmospheric $\mathrm{CO}_{2}$ whilst the other

409 increasing air humidity, have both shown that deciduous tree species can respond

410 to changing atmospheric conditions by prolonging their growing season. This

411 effect, however, is not universal and appears species-specific. Further, the ability 
412 of trees to respond to changing atmospheric composition by retaining their foliage

413 for longer may be modified by interaction with other factors. This research shows

414 that the recently observed increasing duration of foliage cover in forests may not

415 only be an effect of increasing tropospheric temperature, but also be driven

416 directly by changing atmospheric composition.

417

418 Acknowledgements

419 The FAHM study was supported by the Ministry of Education and Science of 420 Estonia (grant SF SF0180025s12) and by the EU through the European Social 421 Fund (Mobilitas postdoctoral grant MJD 257) and the European Regional 422 Development Fund (Centre of Excellence ENVIRON). The development of 423 BangorFACE site infrastructure was funded by SRIF. We thank the Aberystwyth 424 and Bangor Universities Partnership Centre for Integrated Research in the Rural 425 Environment and the Forestry Commission Wales for financially supporting the 426 running costs of the experiment. Andrew Smith was supported by the Sir 427 Williams Roberts PhD Scholarship match funded by the Drapers' Company.

\section{References}

431 Ahmed IUMT (2006) Leaf decomposition of birch (Betula pendula), alder (Alnus glutinosa) and beech (Fagus sylvatica) grown under elevated atmospheric $\mathrm{CO}_{2}$. Dissertation, Bangor University 
434 Ainsworth EA, Long SP (2005) What have we learned from 15 years of free-air

435

436

437

438

439

440

441
$\mathrm{CO}_{2}$ enrichment (FACE)? A meta-analytic review of the responses of photosynthesis, canopy properties and plant production to rising $\mathrm{CO}_{2}$. New Phytol. 165(2):351-371

Buchanan-Wollaston V (1997) The molecular biology of leaf senescence. J Exp Bot 48:181-199

Chang H, Jones ML, Banowetz GM, Clark DG (2003) Overproduction of cytokinins in petunia flowers transformed with $\mathrm{P}_{\mathrm{SAG} 12-\mathrm{IPT}}$ delays corolla senescence and decreases sensitivity to ethylene. Plant Physiol 132:1-10

Dong H, Niu Y, Li W, Zhang D (2008) Effects of cotton rootstock on endogenous cytokinins and abscisic acid in xylem sap and leaves in relation to leaf senescence. J Exp Bot 59:1295-1304

Eamus D, Jarvis PG (1989) The direct effects of increases in the global atmospheric $\mathrm{CO}_{2}$ concentration on natural and commercial temperate trees and forests. Adv Ecol Res19:1-55

Ferreira V, Gonçalves AL, Godbold DL, Canhoto C (2010) Effect of increased atmospheric $\mathrm{CO}_{2}$ on the performance of an aquatic detritivore through changes in water temperature and litter quality. Glob Chang Biol 16: 3284-3296

Hansen R, Mander Ü, Soosaar K, Maddison M, Lõhmus K, Kupper P, Kanal A, Sõber J (2013) Greenhouse gas fluxes in an open air humidity manipulation experiment. Landsc Ecol 28(4):637-649 
Herrick JD, Thomas RB (2003) Leaf senescence and late-season net photosynthesis of sun and shade leaves of overstory sweetgum (Liquidambar styraciflua) grown in elevated and ambient carbon dioxide concentrations. Tree Physiol 23:109-118

IPCC (2013) Climate Change 2013: The Physical Science Basis. Cambridge University Press, Cambridge

Iverson CM (2010) Digging deeper: fine-root response to rising atmospheric $\mathrm{CO}_{2}$ concentration in forested ecosystems. New Phytol 186:346-357

Kont A, Jaagus J, Aunap R (2003) Climate change scenarios and the effect of sealevel rise for Estonia. Glob Planet Change 36:1-15

Kupper P, Sõber J, Sellin A, Lõhmus K, Tullus A, Räim O, Lubenets K, Tulva I, Uri V, Zobel M, Kull O, Sõber A (2011) An experimental facility for Free Air Humidity Manipulation (FAHM) can alter water flux through deciduous tree canopy. Environ Exp Bot 72 (3):432-438

Li JH, Dijkstra P, Hymus GJ, Wheeler RM, Piastuch WC, Hinkle CR, Drake BR (2000) Leaf senescence of Quercus myrtifolia as affected by long-term $\mathrm{CO}_{2}$ enrichment in its native environment. Glob Chang Biol 6:727-733

Lim PO, Kim HJ, Name HG (2007) Leaf senescence. Ann Rev Plant Biol 58:115136

Leutzinger S, Hätenschwiler S (2013) Beyond global change: lessons from 25 years of CO2 research. Oecologia 171:639-651

Menzel A, Sparks TH, Estrella N, Koch E, Aasa A, Ahas R, Alm-Kubler K, Bissolli P, Brasklavska O, Briede A, Chmielewski FM, Crepinsek Z, 

(2006) European phenological response to climate change matches the warming pattern. Glob Chang Biol 12:1-8.

Morris K, A-H-Mackerness S, Page T, John F, Murphy AM, Carr JP, BuchananWollaston V (2000) Salicylic acid has a role in regulating gene expression during leaf senescence. Plant J 23:677-685

Murakami PF, Schaberg PG, Shane JB (2008) Stem girdling manipulates leaf sugar concentrations and anthocyanin expression in sugar maple trees during autumn. Tree Physiol 28:1467-1473

Parts K, Tedersoo L, Lõhmus K, Kupper P, Rosenvald K, Sõber A, Ostonen I (2013) Increased air humidity and understory composition shape short root traits and the colonizing ectomycorrhizal fungal community in silver birch stand. ForEcol Manag 310:720-728

Quirino BF, Noh YS, Himelblau E, Amasino RM (2000) Molecular aspects of leaf senescence. Plant Sci 5:278-282

Schaberg PG, Murakami PF, Turner MR, Heitz HK, Hawley GJ (2008) Association of red coloration with senescence of sugar maple leaves in autumn. Trees 22:573-578

Sellin A, Tullus A, Niglas A, Õunapuu E, Karusion A, Lõhmus K (2013) Humidity-driven changes in growth rate, photosynthetic capacity, 

pendula). Ecol Res 28:523-535

Sigurdsson BD (2001) Elevated $\left[\mathrm{CO}_{2}\right]$ and nutrient status modified leaf phenology and growth rhythm of young Populus trichocarpa trees in a 3-year field study. Trees 15:403-413

Smith AR, Lukac M, Hood R, Healey JR, Miglietta F, Godbold D (2013a) Elevated $\mathrm{CO}_{2}$ enrichment induces a differential biomass response in a mixed species temperate forest plantation. New Phytol 198:156-168

Smith AR, Lukac M, Bambrick M, Miglietta F, Godbold DL (2013b) Tree species diversity interacts with elevated $\mathrm{CO}_{2}$ to induce a greater root system response. Glob Chang Biol 19:217-228

Swartzberg D, Hanael R, Granot D (2010) Relationship between hexokinase and cytokinin in the regulation of leaf senescence and seed germination. Plant Biol 13:439-444

Tallis MJ, Lin Y, Rogers A, Zhang J, Street NR, Miglietta F, Karnosky DF, De Angelis P, Calfapietra C, Taylor G (2010) The transcriptome of Populus in elevated $\mathrm{CO}_{2}$ reveals increased anthocyanin biosynthesis during delayed autumnal senescence. New Phytol 186:415-428

Taylor G, Tallis MJ, Giardina CP, Percy KE, Miglietta F, Gupta PS, Gioli B, Calfapietra C, Gielen B, Kubiske MEM, Scarascia-mugnozza GE, Kets K, Long SP, Karnosky DF (2008) Future atmospheric $\mathrm{CO}_{2}$ leads to delayed autumnal senescence. Glob Chang Biol 14:264-275 
523 Tullus A, Kupper P, Sellin A, Parts L, Sõber J, Tullus T, Lõhmus K, Sõber A,

524 Tullus H (2012a) Climate Change at Northern Latitudes: Rising

525 Atmospheric Humidity Decreases Transpiration, N-uptake and Growth

$526 \quad$ Rate of Hybrid Aspen. PLoS ONE 7(8):e42648

527 Tullus A, Rytter L, Tullus T, Weih M, Tullus H (2012b) Short-rotation forestry

528 with hybrid aspen (Populus tremula L. $\times$ P. tremuloides Michx.) in

529 Northern Europe. Scand J For Res 27:10-29

530 Winger A, Purdy S, MacLean JA, Poutau N (2006) The role of sugars in

531 integrating environmental signals during leaf senescence. J Exp Bot

$532 \quad 57: 391-399$

533 Yendrik CR, Leisner CP, Ainsworth EA (2013). Chronic ozone exacerbates the

534 reduction in photosynthesis and acceleration of senescence caused by

$535 \quad$ limited N availability in Nicotiana sylvestris. Glob Chang Biol 19: 3155-

$536 \quad 3166$

537 Yong JWH, Wong SC, Letham DS, Hocart CH, Farquhar GD (2000) Effects of

538 elevated $\left[\mathrm{CO}_{2}\right]$ and nitrogen nutrition on cytokinins in the xylem sap and

$539 \quad$ leaves of cotton. Plant Physiol 124:767-779

540 Zak DR, Pregitzer KS, Kubiske ME, Burton AJ (2011) Forest productivity under

541 elevated $\mathrm{CO}_{2}$ and $\mathrm{O}_{3}$ : positive feedbacks to soil $\mathrm{N}$ cycling sustain decade-

$542 \quad$ long net primary productivity enhancement by $\mathrm{CO}_{2}$. Ecol Lett 14: 1220-

5431226.

544 Zhou L, Tucker CJ, Kaufmann RK, Slayback D, Shabanov NV, Myneni, RB

545 (2001) Variations in northern vegetation activity inferred from satellite 

20083

548 
549 Table 1. Environmental variables and the lifespan of the leaf canopy (bud-burst to

550 final leaf fall) in Betula pendula at BangorFACE throughout the four years of $\mathrm{CO}_{2}$

551 enrichment. The effect of elevated $\mathrm{CO}_{2}$ on canopy lifespan is shown in

552 parenthesis in days. $\mathrm{T}_{\min }$ and $\mathrm{T}_{\max }$ are based on the daily minimum and maximum

553 temperatures. GDD = growing degree days. GDD $=\left(\frac{T_{\min }+T_{\max }}{2}\right)-10$.

554

\begin{tabular}{cccccccc}
\hline Year & $\begin{array}{c}\mathrm{T}_{\min } \\
\left({ }^{\circ} \mathrm{C}\right)\end{array}$ & $\begin{array}{c}\mathrm{T}_{\max } \\
\left({ }^{\circ} \mathrm{C}\right)\end{array}$ & $\begin{array}{c}\text { GDD } \\
(\text { base } \\
\left.10^{\circ} \mathrm{C}\right)\end{array}$ & $\begin{array}{c}\text { Rain } \\
(\mathrm{mm})\end{array}$ & $\begin{array}{c}\text { Ozone } \\
(\text { AOT40) }\end{array}$ & $\begin{array}{c}\text { Ambient } \mathrm{CO}_{2} \\
\text { canopy lifespan } \\
\text { (days) }\end{array}$ & $\begin{array}{c}\text { Elevated } \mathrm{CO}_{2} \\
\text { canopy } \\
\text { lifespan } \\
\text { (days) }\end{array}$ \\
\hline 2005 & -3.5 & 27.0 & 1910 & 726 & 9058 & 201 & $201(+0)$ \\
2006 & -5.5 & 34.3 & 2065 & 1111 & 12931 & 176 & $190(+14)$ \\
2007 & -3.3 & 24.3 & 1672 & 705 & 3783 & 172 & $172(+0)$ \\
2008 & -4.5 & 25.4 & 1788 & 1077 & 7561 & 165 & $177(+12)$ \\
\hline
\end{tabular}

555

556 
Table 2. Environmental variables and the lifespan of the leaf canopy (bud-burst to final leaf fall) at FAHM throughout the five years of relative humidity $(\mathrm{RH})$ manipulation. The effect of FAHM on canopy lifespan is shown in parenthesis in days. $\mathrm{T}_{\min }$ and $\mathrm{T}_{\max }$ are based on the average annual minimum and maximum temperatures. GDD $=$ growing degree days. GDD $=\left(\frac{T_{\min }+T_{\max }}{2}\right)-10$

560

\begin{tabular}{|c|c|c|c|c|c|c|c|c|c|}
\hline \multirow[t]{2}{*}{ Year } & \multirow[t]{2}{*}{$\begin{array}{l}\mathrm{T}_{\min } \\
\left({ }^{\circ} \mathrm{C}\right)\end{array}$} & \multirow[t]{2}{*}{$\begin{array}{l}\mathrm{T}_{\max } \\
\left({ }^{\circ} \mathrm{C}\right)\end{array}$} & \multirow[t]{2}{*}{$\begin{array}{c}\text { GDD } \\
\text { (base } 10^{\circ} \mathrm{C} \text { ) }\end{array}$} & \multirow[t]{2}{*}{$\begin{array}{l}\text { Rain (May-Oct) } \\
\text { (mm) }\end{array}$} & \multirow{2}{*}{$\begin{array}{l}\text { Total } \\
\text { precip. } \\
(\mathrm{mm})\end{array}$} & \multicolumn{2}{|c|}{$\begin{array}{l}\text { Ambient RH canopy lifespan } \\
\text { (days) }\end{array}$} & \multicolumn{2}{|c|}{$\begin{array}{l}\text { Elevated RH canopy lifespan } \\
\text { (days) }\end{array}$} \\
\hline & & & & & & $50 \%$ fallen & $\begin{array}{l}100 \% \\
\text { fallen }\end{array}$ & $50 \%$ fallen & $100 \%$ fallen \\
\hline \multirow[t]{2}{*}{2008} & -17.1 & 30.8 & 619 & 502 & 853 & Aspen: 156 & 170 & $156(+0)$ & $170(+0)$ \\
\hline & & & & & & Birch: 168 & 205 & $177(+9)$ & $205(+0)$ \\
\hline \multirow[t]{2}{*}{2009} & -20.7 & 30.7 & 1015 & 468 & 696 & Aspen: 160 & 190 & $160(+0)$ & $190(+0)$ \\
\hline & & & & & & Birch: 145 & 211 & $166(+21)$ & $211(+0)$ \\
\hline \multirow[t]{2}{*}{2010} & -27.6 & 36.9 & 1321 & 387 & 828 & Aspen: 151 & 193 & $137(-14)$ & $193(+0)$ \\
\hline & & & & & & Birch: 123 & 205 & $163(+40)$ & $205(+0)$ \\
\hline \multirow[t]{2}{*}{2011} & -28.8 & 32 & 1043 & 261 & 669 & Aspen: 154 & 178 & $154(+0)$ & $178(+0)$ \\
\hline & & & & & & Birch: 141 & 192 & $153(+12)$ & $192(+0)$ \\
\hline \multirow[t]{2}{*}{2012} & -31.3 & 32.9 & 753 & 339 & 756 & Aspen: 140 & 171 & $140(+0)$ & $171(+0)$ \\
\hline & & & & & & Birch: ${ }^{* *}$ & -** $^{* *}$ & $-{ }^{* *}$ & $-{ }^{* *}$ \\
\hline
\end{tabular}




\section{Figure legends}

564 Fig. 1. Monthly mean air temperature (line) and total precipitation (columns) at

565 (a) BangorFACE during the years 2005-2008 and at (b) FAHM during the 566 growing seasons 2008-2012.

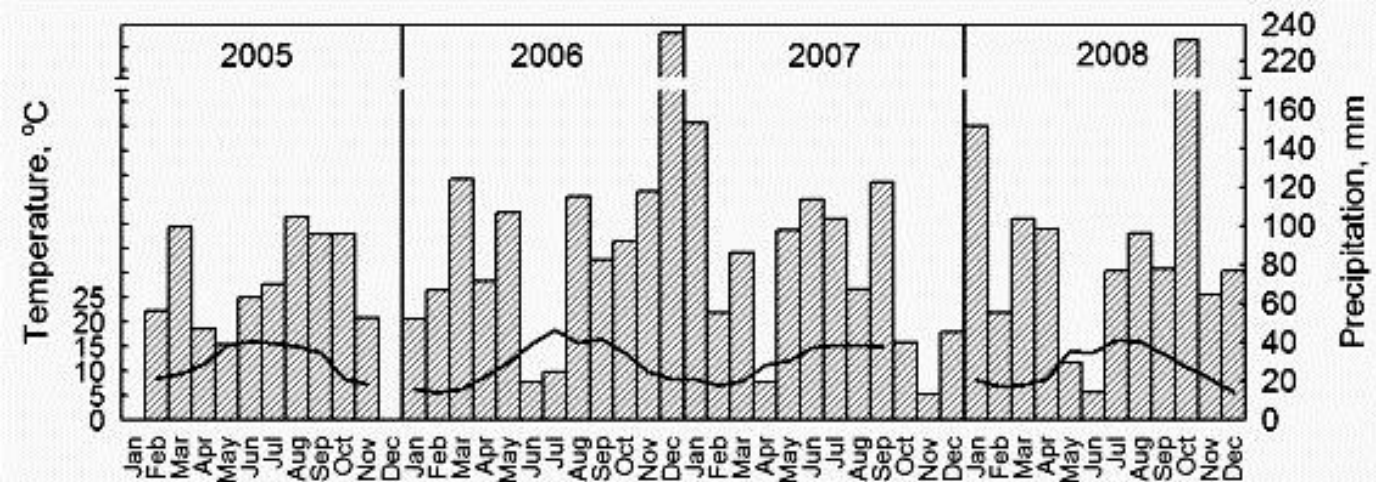

a) Month

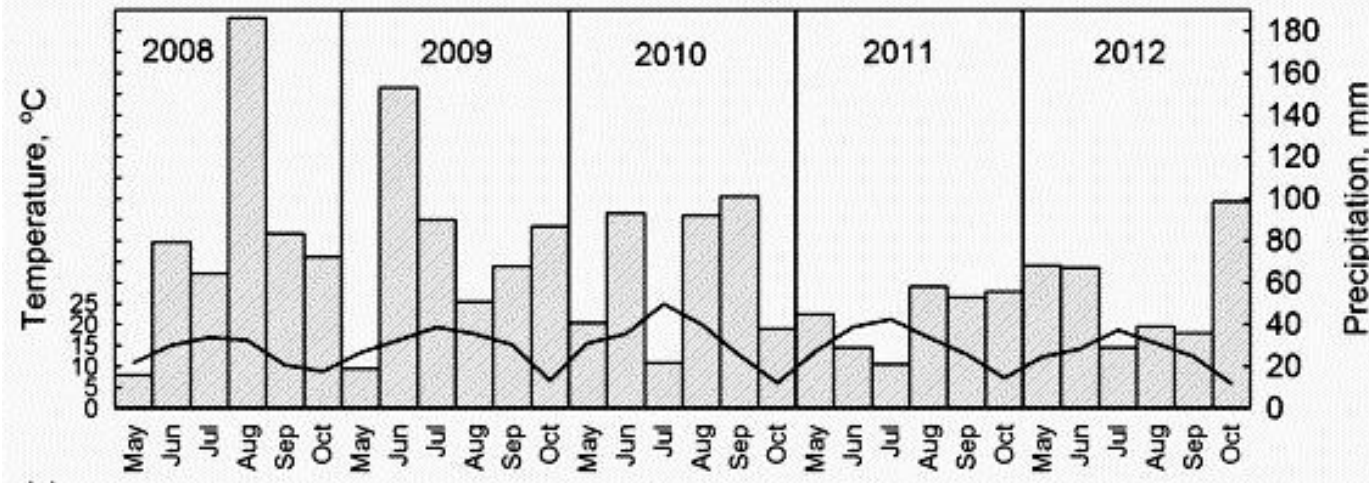

b)

Month 
569 Fig. 2. Percentage leaf mass remaining in the canopy of birch (Betula pendula)

570 and hybrid aspen (Populus tremula $\times$ tremuloides) grown at ambient humidity or

571 increased humidity (FAHM). Data points show mean \pm SE. $n=3$.

572

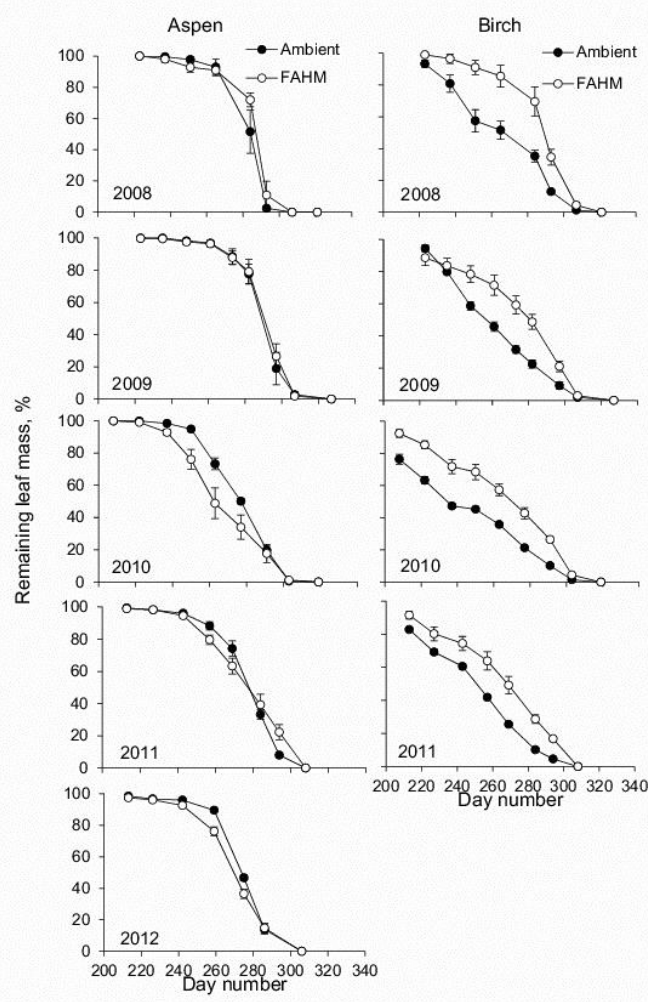


574 Fig. 3. Percentage leaf mass remaining in the canopy of birch (Betula pendula)

575 and hybrid aspen (Populus tremula $\times$ tremuloides) grown at ambient humidity or

576 increased humidity (FAHM). Model predictions (solid lines) and 95\% confidence

577 intervals (dashed lines) are shown for leaf mass remaining over time for

578 individual years in the ambient (black) and elevated (grey) humidity treatments.
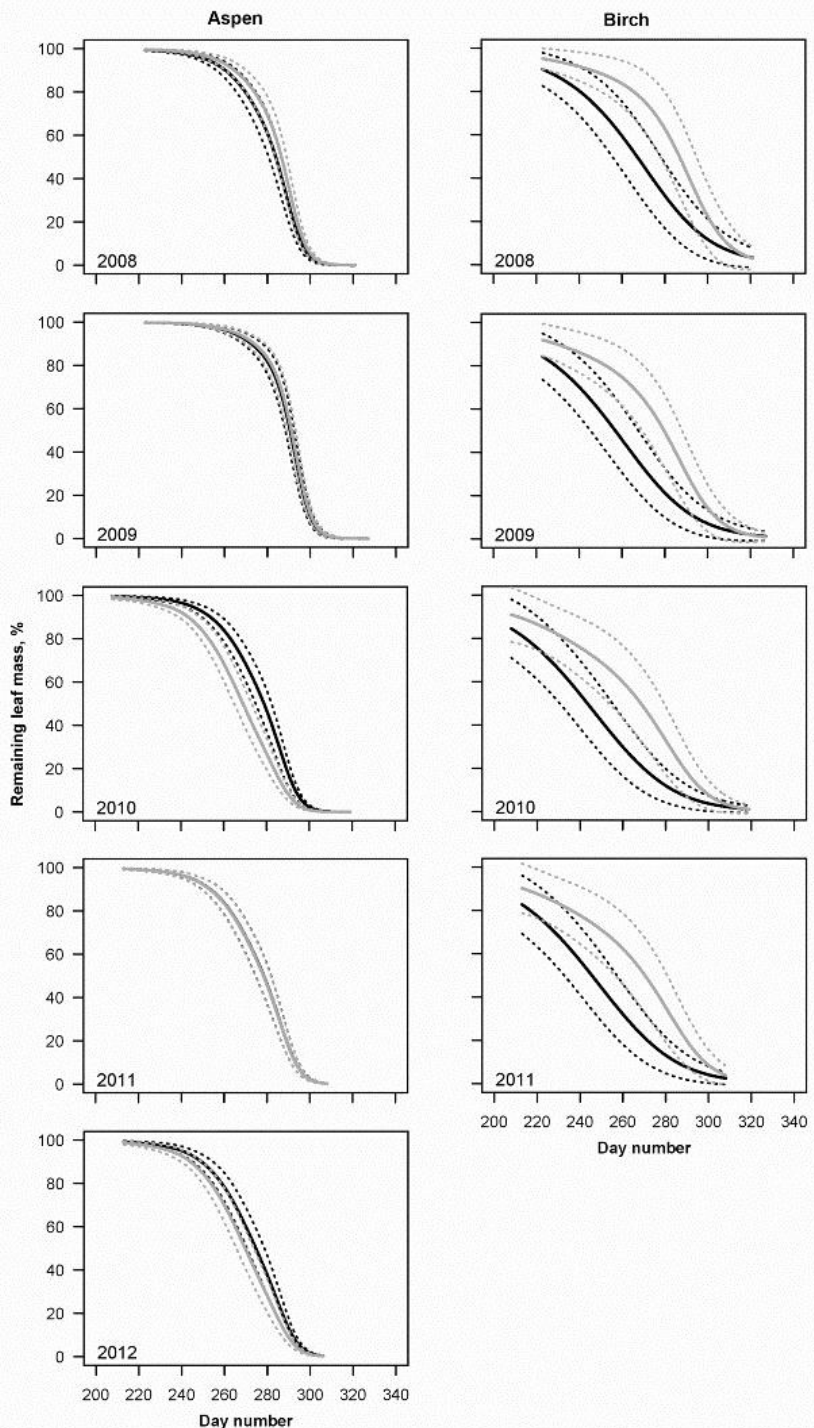

Day number 
Fig. 4. Percentage leaf mass remaining in the canopy of birch (Betula pendula)

583 and alder (Alnus glutinosa) grown at ambient or elevated atmospheric $\mathrm{CO}_{2}$

584 (FACE). Data points show mean \pm SE. $n=4$.
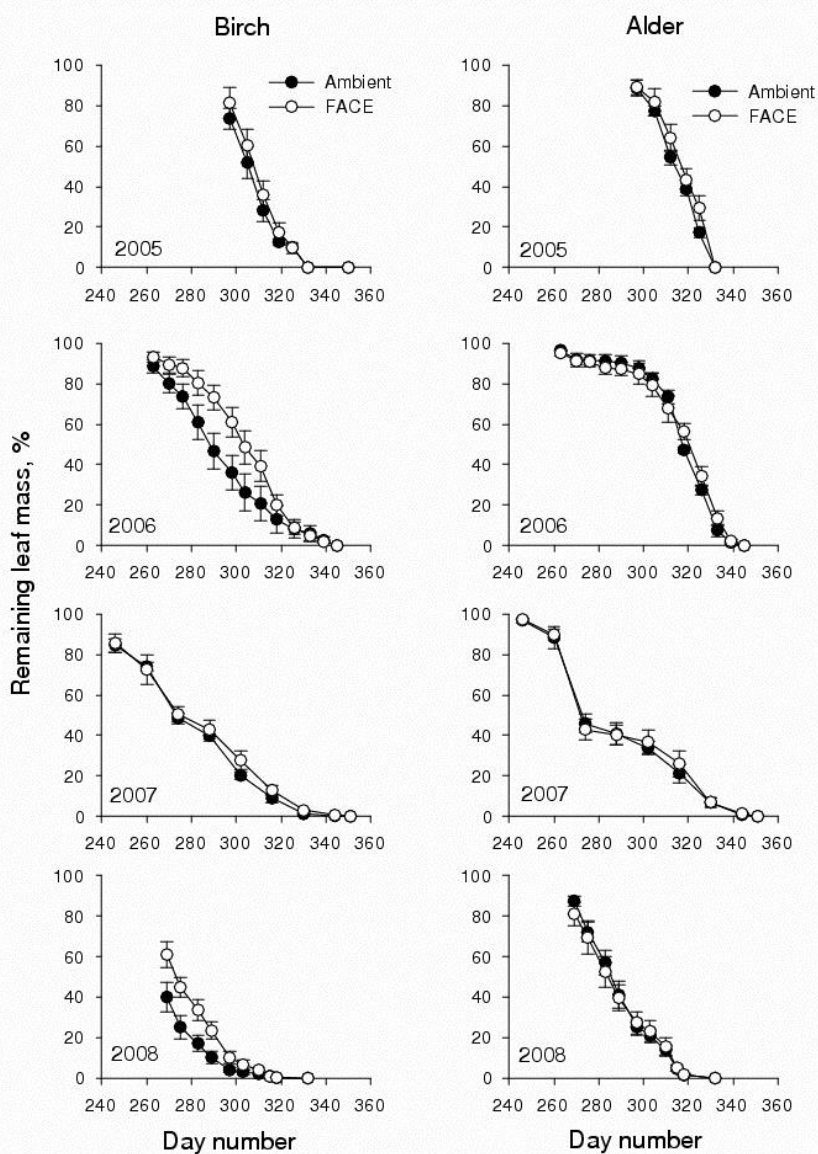

Day number 
587 Fig. 5. Percentage leaf mass remaining in the canopy of birch (Betula pendula)

588 and alder (Alnus glutinosa) grown at ambient or elevated atmospheric $\mathrm{CO}_{2}$

589 (FACE). Model predictions (solid lines) and 95\% confidence intervals (dashed

590 lines) are shown for leaf mass remaining over time. In Betula pendula this is for

591 the individual years in the ambient (black) and elevated (grey) $\mathrm{CO}_{2}$ treatments. In

592 Alnus glutinosa shown are the individual years with the treatments combined, as

593 there are no treatment effects, but a significant difference between 2007 and the

594 other years.

595
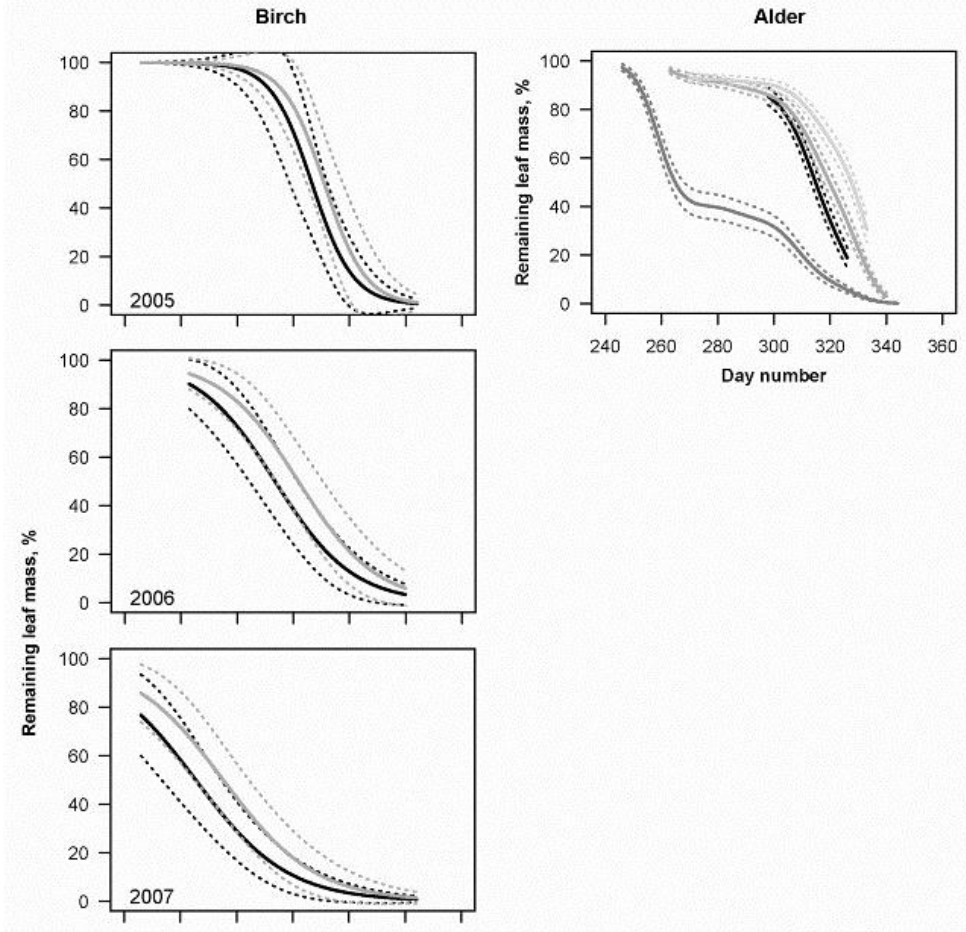

Day number

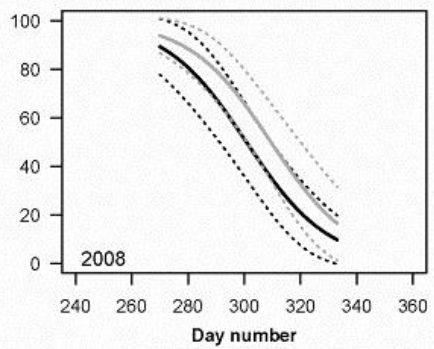

